\title{
Human parvovirus B19 infection in HIV-positive patients
}

\author{
Infecção por parvovirus humano B19 em pacientes HIV-positivos
}

\author{
Fábio S. Aguiar ${ }^{1}$, Daniella P. Lopes ${ }^{1}$, Anna Ricordi Bazin ${ }^{2}$, Sérgio Setúbal ${ }^{2}$, Bernard J. Cohen ${ }^{3}$ \\ and Jussara P. Nascimento 1,4
}

\begin{abstract}
Parvovirus B19 infects predominantly erythroid cells, leading to transient inhibition of erythropoiesis. Immunocompromised patients may be unable to produce neutralizing antibodies and may develop severe chronic anemia. Epidemiological studies done on Niterói population showed that B19 infection occurs periodically in late spring and summer. We report a study from 55 HIV infected patients attending an infectious diseases outpatient clinic in this city during a 5-month period in which B19 circulation was well documented. All patients were under anti-retroviral therapy. No anti-B19 IgM was found, but a high prevalence of Ig G anti-B19 (91\%) was observed. In six patients, B19 DNA was found by dot-blot hybridization techniques, but this was not confirmed by PCR. None of these 6 patients manifested anemia and only one had CD4 cell count below $200 \times 10^{7} / \mathrm{L}$. We conclude that persistent infection causing anemia is an infrequent finding in our HIV positive patients under drug therapy.
\end{abstract}

Key-words: Parvovirus B19. AIDS. Chronic anemia. Opportunistic infection.

Resumo O parvovírus B19 infecta predominantemente células eritróides, causando inibição transitória da eritropoiese. Pacientes imunocomprometidos podem ser incapazes de produzir anticorpos neutralizantes, evoluindo com grave anemia crônica. Estudos epidemiológicos da população de Niterói mostraram que a infecção ocorre periodicamente no final da primavera e no verão. Descrevem-se 55 pacientes infectados pelo HIV atendidos num ambulatório de doenças infecciosas nesta cidade num período de cinco meses, no qual a circulação do parvovírus B19 foi documentada. Todos os pacientes estavam sob terapia anti-retroviral. Não se encontrou IgM anti-B19, mas notou-se uma prevalência alta de IgG anti-B19 (91\%). Em seis pacientes verificouse a presença de DNA do B19 por hibridização em dot-blot, o que não se confirmou por PCR. Nenhum destes seis pacientes tinha anemia, e apenas um tinha células CD4 abaixo de $200 \times 10^{7} / \mathrm{L}$. Conclui-se que infecção persistente causando anemia é um achado infreqüente em nossos pacientes HIV positivos sob terapia medicamentosa.

Palavras-chaves: Parvovirus B19. AIDS. Anemia Crônica. Infecção Oportunista.

Human Parvovirus B19 is a member of the Parvoviridae family and infects predominantly erythroid stem cells. This results in transient inhibition of erythropoiesis5. The infection occurs normally in childhood and has been linked to a long known exanthematic disease, erythema infectiosum. It may also cause arthritis and arthralgia in women, through deposition of immunocomplexes in the joints ${ }^{8}$. However, the infection is often asymptomatic. In immunocompromised patients, B19 infection causes severe chronic anemia due to inability to produce neutralizing antibodies, and consequent persistence of virus replication 14. The virus has a worldwide distribution. Epidemiological studies done from 1994 to 1998 in Niterói, a medium-sized city in Rio de Janeiro State, Brazil, showed that B19 activity occurs periodically each year, commonly in the form of outbreaks in late spring and summer ${ }^{20}$.

In this study we examined the prevalence of antiB19 IgG antibodies, and sought evidence of persistent B19 infection, in HIV infected individuals attending the outpatient clinic of the Infectious Diseases Department of Hospital Universitário Antônio Pedro, a public tertiary care university hospital in Niterói.

\footnotetext{
1. Departamento de Microbiologia e Parasitologia, Universidade Federal Fluminense, Niterói. 2. Disciplina de Doenças Infecciosas e Parasitárias do Hospital Universitário Antônio Pedro da Universidade Federal Fluminense, Niterói. 3. Virus Reference Division, Central Public Health Laboratory, Colindale, London. 4. Departamento de Desenvolvimento Tecnológico, BioManguinhos, FIOCRUZ, Rio de Janeiro, RJ.

Supported by grants $\mathrm{n}-520897 / 96$ from the Conselho Nacional de Desenvolvimento Científico e Tecnológico (CNPQ) and from a FIOCRUZ/ Britsh Council Agreement

Address to: Dr. Sergio Setúbal. Disciplina de Doenças Infecciosas e Parasitárias/UFF. R. Marquês do Paraná 303, Centro, 22030-210 Niterói, RJ.

Fax: $5521719-7262$

e-mail: labutes@attglobal.net

Recebido para publicação em 27/07/2000.
} 


\section{MATERIAL AND METHODS}

Patients - Between September 1997 and January 1998 clinical data were collected and serum samples from 55 HIV-infected outpatients. A second specimen was collected one year later from three of the six patients suspected to have persistent B19 infection by DNA detection in the first serum sample. The patients were divided into categories $\mathrm{A}, \mathrm{B}$ and $\mathrm{C}$ according to the CDC HIV classification, 1992 (Table 1$)^{2}$. The male-female ratio was 1.48 . The age range was 21 to 50 years, with a median of 36 years. The median time elapsed since the diagnosis of HIV infection was 5.3 years. All patients were under some kind of anti-retroviral drug therapy.

Serologic assays - All sera were examined by a $\mu$ capture enzyme immunoassay (MACEIA) to detect anti$\mathrm{B} 19 \mathrm{lgM}$ as described by Cubel et $\mathrm{al}^{9}$ and Nascimento et $\mathrm{al}^{19}$. An indirect immunofluorescence test (IFA) was

Table 1 - Patients classification in CDC categories2*.

\begin{tabular}{lccc}
\hline \multicolumn{4}{c}{ Categories (CDC, 1992) } \\
\hline $\mathrm{A}$ & $\mathrm{B}$ & $\mathrm{C}$ & Not classified \\
\hline $4.2 \%$ & $29.8 \%$ & $40.5 \%$ & $25.5 \%$ \\
\hline${ }^{*} \mathrm{CD} 4$ cell count not available for all patients \\
$\mathrm{N}=55$
\end{tabular}

used to detect anti-B19 $\lg \mathrm{G}^{21}$. In order to detect B19 DNA a dot-blot test was used as described by Mori et $\mathrm{al}^{15}$. Three different samples taken from a 32-year-old HIV positive male with chronic anemia due to persistent B19 infection were used as a positive control. Positive B19 DNA samples were sent to the Virus Reference
Division of the Central Public Health Laboratory, in the United Kingdom, for confirmation of the diagnosis by nested PCR7, and by dot-blot using chemiluminescent detection ${ }^{116}$. All sera, including the positive and negative controls, were stored at $-20^{\circ} \mathrm{C}$ and heated to $60^{\circ} \mathrm{C}$ during 20 minutes before testing.

\section{RESULTS}

Table 2 shows that $91 \%(50 / 55)$ of the patients had anti-B19 $\lg$. None of the patients had anti-B19 IgM. B19 DNA was found in six (11\%) patients, albeit in lower amounts than in our positive control. These six patients (one female and five males) were classified as class $C(n=4)$ and $B(n=2)$, according to the CDC criteria. None of them showed laboratory evidence of anemia (all had hematocrit $>40 \%$ and reticulocytes $\cong 1 \%$ ) and only one had a CD4 cell count lower than $200 \times 10^{7 /} \mathrm{L}$. The laboratory findings for these six DNA positive patients are listed in Table 3. For three of them, DNA detection was confirmed using a dot blot hybridization with chemiluminescent detection method, but not by PCR. Three patients had a second sample taken one year later. No B19 DNA was found in these samples.

Table 2 - Anti-B19 antibodies and B19 DNA results for the 55 HIV infected patients.

\begin{tabular}{|c|c|c|c|c|c|c|}
\hline \multirow[t]{2}{*}{ Patients } & \multicolumn{2}{|c|}{ Anti-B19 IgG (IFA) } & \multicolumn{2}{|c|}{ Anti-B19 IgM (MACEIA) } & \multicolumn{2}{|c|}{ B19 DNA (Dot-Blot) } \\
\hline & Positive & Negative & Positive & Negative & Positive & Negative \\
\hline $\mathrm{N}=55$ & 50 & 5 & 0 & 55 & 6 & 49 \\
\hline Percentages & 91 & 9 & 0 & 100 & 11 & 89 \\
\hline
\end{tabular}

Table 3 - Laboratory findings for the 6 patients suspected of having persistent B19 infection.

\begin{tabular}{|c|c|c|c|c|c|c|c|c|}
\hline \multirow{3}{*}{$\begin{array}{l}\text { Patient } \\
\text { no }\end{array}$} & \multirow{3}{*}{ Sex } & \multirow{3}{*}{ CDC Class } & \multirow{3}{*}{$\begin{array}{c}\text { Sample collection } \\
\text { Month/Year }\end{array}$} & \multicolumn{2}{|c|}{ Anti-B19 Antibodies } & \multicolumn{3}{|c|}{ B19 DNA } \\
\hline & & & & \multirow[t]{2}{*}{$\lg G(I F A)$} & \multirow{2}{*}{$\begin{array}{l}\lg M \\
\text { MACEIA }\end{array}$} & \multicolumn{2}{|c|}{ Dot Blot } & \multirow[t]{2}{*}{ PCR } \\
\hline & & & & & & $A$ & $B$ & \\
\hline 10 & $M$ & ND & S1 11/97 & Neg VP1 and VP2 & $\mathrm{Neg}$ & + & + & - \\
\hline 38 & M & $\mathrm{C}$ & S1 12/97 & Pos VP1 and VP2 & Neg & + & + & - \\
\hline \multirow[t]{2}{*}{50} & $\mathrm{~F}$ & $\mathrm{C}$ & S1 01/98 & Pos VP1 and VP2 & $\mathrm{Neg}$ & + & + & - \\
\hline & & & S2 04/99 & Pos WB VP1 & $\mathrm{Neg}$ & ND & - & - \\
\hline \multirow[t]{2}{*}{53} & M & $\mathrm{C} 1$ & S1 01/98 & Neg VP1 and VP2 & Neg & + & - & - \\
\hline & & & S2 02/99 & ND & & ND & - & ND \\
\hline \multirow[t]{2}{*}{58} & M & ND & S1 02/98 & Pos VP1 and VP2 & $\mathrm{Neg}$ & + & - & ND \\
\hline & & & S2 04/99 & ND & & & - & \\
\hline 60 & $M$ & ND & S1 02/98 & Neg VP1 pos VP2 & Neg & + & - & ND \\
\hline
\end{tabular}




\section{DISCUSSION}

Anemia is a common finding in the HIV infected patient ${ }^{12}$. Up to $80 \%$ of these patients are anemic, a percentage that increases as the infection advances ${ }^{13}$. Several causes of anemia have been described in HIV positive patients ${ }^{13}$, such as the drugs used in the course of treatment (zidovudine, trimethoprim-sulfamethoxazole), lymphomas, the direct effect of HIV on bone marrow cells and coinfection with mycobacteria or human parvovirus B19. The diagnosis of B19 infection in anemic HIV patients is important, since chronic B19 viremia is a treatable cause of anemia in this population ${ }^{1013}$.

IgG antibodies to B19 are usually found in immunocompetent adults in rates that varies from $60 \%$ to $80 \%$. Among HIV infected groups, however, the prevalence has shown a large variation. The initial studies, involving a small number of patients, showed a higher prevalence of $\lg G$ antibodies to $\mathrm{B} 19$, when compared with immunocompetent individuals ${ }^{31724}$. Recent studies involving larger groups of patients confirmed this higher seroprevalence among anemic HIV-infected patients ${ }^{23}$. On the other hand, van Elsacker-Niele et $\mathrm{al}^{22}$, studying 317 consecutive HIV infected patients searching for B19 DNA and antibodies, have found no difference in seroprevalence rates between the anemic and non-anemic HIV groups, as well as between HIV patients and normal immunocompetent individuals. B19 DNA was not detected among the patients and the authors concluded that parvovirus B19 infection has a limited role in the anemia of HIV infected patients.

Patients infected with HIV may be incapable of producing IgG antibodies against parvovirus B19, but even among the more immunocompetent individuals such antibodies may be unable to neutralize the virus, leading to persistent infections ${ }^{14}$. Patients with a CD4 count of over $300 \times 10^{6}$ cells/L are usually capable of producing neutralizing antibodies, and persistent infections are more common among patients with advanced immunodeficiency. The degree of immunodeficiency and other confounding factors could explain the difference found in the IgG seroprevalence in different studies.

Controversial findings have also been reported in the literature regarding the persistence of B19 infection in HIV positive patients. Naides et $\mathrm{al}^{17}$ found a high rate of B19 persistence in a highly selected AIDS population. On the other hand, Bremner et $\mathrm{al}^{4}$, studying 39 HIV positive patients with anemia (B19 viremia-negative by nested-PCR), concluded that B19 infection is an uncommon cause of anemia in the HIV positive population, especially in non epidemic years. Vernazza et $\mathrm{al}^{23}$ described persistent B19 infection as an uncommon cause of anemia in these patients, due to preservation of an adequate humoral immune response until the late stages of HIV infection. Since persistent parvovirus B19 chronic infection is typically associated with absence of an antibody response to $\mathrm{B}^{1} \mathrm{9}^{6}$, the continued ability to synthesize antibodies would render B19 chronic infection with anemia uncommon.

In the present paper we studied a non-anemic population of HIV positive patients for anti-B19 antibodies (IgM and $\lg G$ ) and B19 DNA. We did not detect IgM antibodies in any of the samples, but we found a significantly higher prevalence of $\lg$ G antibodies to B19 in this group (91\%) than among general population matched by age, as inferred by the previous population studied by Nascimento et al ${ }^{18}$.

B19 DNA was found in the sera of six (10.9\%) patients by dot-blot hybridization, although in lower amount than in our viremic control samples. Chemiluminescent detection was positive for 3 of the 6 samples. These findings were not confirmed by a more sensitive PCR technique, which was subsequently performed on 5 of the 9 samples. These 6 patients ( 5 male and 1 female) were classified accordingly to the CDC 1992 criteria as belonging to class $C$ (four) and $B$ (two). None of them had anemia. Only one had a CD4 cell count lower than $200 \times 10^{7} / \mathrm{L}$. Five of these patients were positive for anti-B19 lgG antibodies, and only one was IgG negative.

We conclude that B19 IgG antibody prevalence was high in our patients and, although six of them were positive by a DNA dot-blot, we were unable to confirm persistent B19 infection by PCR. Chronic anemia due to B19 infection was not found in our HIV positive patients under drug therapy.

\section{REFERENCES}

1. Abkowitz JL, Brown KE, Wood RW, Kovach NL, Green SW, Young NS. Clinical relevance of parvovirus B19 as a cause of anemia in patients with human immunodeficiency virus infection. Journal of Infectious Diseases 176:269-273, 1997.

2. Anonymous. Morbidity and Mortality Weekly Report 42 (RR-17), 1992.

3. Bremner JAG, Beard S, Cohen BJ, Alimenti A, Cantiniaux B, Levy J. Secondary infection with parvovirus B19 in an HIV positive patient [Letter]. AIDS 7:1131-1132, 1993.
4. Bremner JAG, Cohen BJ. Parvovirus B19 as a cause of anemia in human immunodeficiency virus-infected patients. Journal of Infectious Diseases 169: 938-939, 1994.

5. Brown KE, Young NS. Persistent parvovirus B19 infection. Reviews of Medical Microbiology 6:246-256, 1995.

6. Chernak E, Dubin G, Henry D, Naides SJ, Hodinka RL, MacGregor RR, Friedman HM. Infection due to parvovirus B19 in patients infected with human immunodeficiency virus. Clinical Infectious Diseases 20:170-173, 1995. 
7. Clewley JP. PCR detection of parvovirus B19. In: Persing DH, Senith TF, Tenover TJ (eds) Diagnostic Molecular Microbiology principles and applications. American Society for Microbiology, Washington DC, p. 367-373, 1993.

8. Cohen BJ. Parvovirus B19: an expanding spectrum of disease. British Medical Journal 311:1549-1552, 1995.

9. Cubel RCN, Alferes ACR, Cohen BJ, Nascimento JP. Application to immunoglobulin $M$ capture hemadherence assays to hemagglutination of monkey erythrocytes by native and recombinant human parvovirus B19 antigens. Journal of Clinical Microbiology 32:1997-1999, 1994.

10. Frickhofen N, Abkowitz JL, Safford M, Berry JM, Antunes de Mayolo J, Astrow A, Cohen R, Halperin I, Mintzer D. Persistent B19 parvovirus infection in patients infected with human immunodeficiency virus type 1 (HIV-1): a treatable cause of anemia in AIDS. Annals of Internal Medicine 113: 926-933, 1990.

11. Girotti S, Musiani M, Pasini P, Ferri E, Gallinella G, Zerbini ML, Roda A, Gentilomi G, Venturoli S. Application of a low-light imaging device and chemiluminescent substrates for quantitative detection of viral DNA in hybridization reactions. Clinical Chemotherapy 41:1693-1697, 1995.

12. Gyllensten K, Sonnenborg A, Jorup-Ronstrom C, Halvarsson M, Yun Z. Parvovirus B19 infection in HIV-1 infected patients with anemia. Infection 22:356-358, 1994.

13. Hoxie JA. Hematologic manifestations of AIDS. In: Hoffman R, Benz EJ Jr, Shattil SJ (eds) Hematology: basic principles and practice New York, Churchill Livingstone, p. 2171-200, 1995.

14. Kurtzman GJ, Cohen BJ, Field AM, Oseas R, Blaese RM, Young NS. Immune response to B19 parvovirus and an antibody defect in persistent viral infection. Journal of Clinical Investigation 84:1114-1123, 1989.

15. Mori J, Field AM, Clewley JP, Cohen BJ. Dot-Blot hybridization assay of B19 virus DNA in clinical specimens. Journal of Clinical Microbiology 27:459-464, 1989.

16. Musiani M, Zerbini M, Gibellini D, Gentilomi G, Venturoli S, Gallinella G, Ferri E, Girotti S. Chemiluminescencedot blot hybridization assay for detection of B19 parvovirus DNA in human sera. Journal of Clinical Microbiology 29:2047-2050, 1991.

17. Naides SJ, Howard EJ, Swack NS, True CA, Stapleton JT. Parvovirus B19 isnfection in human immunodeficiency virus type 1 -infected persons failing or intolerant to zidovudine therapy. Journal of Infectious Diseases 168:101-105, 1993.

18. Nascimento JP, Buckley MM, Brown KE, Cohen BJ. The prevalence of antibody to human parvovirus B19 in Rio de Janeiro, Brazil. Revista do Instituto de Medicina Tropical de São Paulo 32:41-45, 1990.

19. Nascimento JP, Mistchenko A, Cohen BJ. Laboratory diagnosis of acute human parvovirus B19 infection by specific lgM detection. Revista do Instituto de Medicina Tropical de São Paulo 40:265266, 1998.

20. Oliveira SA, Brandão AB, Fernandes DG, Bettini LR, Carvalho $A B$, Pereira ACM, Azevedo KM, Nascimento JP. Human parvovirus B19 infection: clinical and epidemiological study of 24 cases. Revista do Instituto de Medicina Tropical de São Paulo 38:323-327, 1996.

21. Pereira RFA. Análise da resposta imune humoral em pacientes infectados pelo parvovírus B19 às proteínas recombinantes expressas em células Sf9. Tese de Mestrado, Instituto Oswaldo Cruz, Rio de Janeiro, RJ, 1985.

22. Van Elsacker-Niele AMW, Kroon FP, van der Ende ME, Salimans MMM, Spaan WJM, Kroes ACM. Prevalence of parvovirus B19 infection in patients infected with human immunodeficiency virus. Clinical Infectious Diseases 23:1255-1260, 1996.

23. Vernazza PL, Pfister LA, Siegl G, Cassinotti P. High seroprevalence of parvovirus B19 among patients infected with human immunodeficiency virus. Clinical Infectious Diseases 22:198-199, 1996

24. Zuckerman NA, Williams I, Bremner J, Cohen B, Miller RF. Persistent anemia in HIV infected individuals due to parvovirus B19 infection [Letter]. AIDS 8:1191-1192, 1994. 